\title{
Akad dalam Perbankan Internet
}

\author{
Anitha Rosland ${ }^{a *}$, Joni Tamkin Borhan ${ }^{a}$ \\ aJabatan Syariah dan Ekonomi, Universiti Malaya, 50603 Kuala Lumpur \\ *Corresponding author: anitharosland@yahoo.com
}

\section{Article history}

Received : 21 March 2013

Received in revised form :

15 October 2013

Accepted :30 October 2013

\begin{abstract}
Way of life nowadays has changed a lot over the years. Even this borderless world has also brought tremendous changes to the existing banking system. Now, Internet banking is the latest alternative used by the client to deal with the bank. In this way, the customer can surf the bank website without the hassles of queuing and waiting at the counter. This study will discuss about Internet banking services in terms of Islamic transaction. Where, this study touches on contract applications found in banking services. The study found that Internet banking services is allowed in Islam and the contract is valid even in the early emergence of Islam's Internet technology sophistication yet exists.
\end{abstract}

Keyword: Internet banking; contract (akad); contract ceremony; ijab and qabul; defects

\section{Abstrak}

Corak hidup masyarakat pada masa kini telah banyak berubah tahun demi tahun. Malah dunia tanpa sempadan ini juga telah membawa perubahan yang sangat besar kepada sistem perbankan yang sedia ada. Pada masa kini, perbankan Internet merupakan alternatif terkini yang diguna pakai oleh pelanggan untuk berurusan dengan bank. Dengan cara ini, pelanggan hanya melayari laman web bank berkenaan tanpa perlu bersusah-payah beratur dan menunggu di kaunter bank. Kajian ini akan membincangkan tentang perkhidmatan perbankan Internet dari sudut muamalah Islam. Di mana, kajian ini menyentuh mengenai aplikasi akad yang terdapat dalam perkhidmatan perbankan Internet. Hasil kajian mendapati bahawa perkhidmatan perbankan Internet ini dibenarkan dalam Islam serta sah akadnya walaupun di awal kemunculan Islam kecanggihan teknologi Internet ini masih lagi belum wujud.

Kata kunci: Perbankan Internet; kontrak (akad); majlis akad; ijab dan qabul; kecacatan

\subsection{PENGENAlan}

Kewujudan Internet mampu menjadikan dunia tanpa sempadan. Dengan erti kata lain, Internet membolehkan kita berhubung dengan sesiapa sahaja tanpa perlu bersua muka dan mengambil masa yang lama. Penggunaan Internet bukan sahaja terhad untuk mencari maklumat, pendidikan, saluran komunikasi, dan hiburan, malah Internet sudah menjadi sumber pendapatan kepada masyarakat. Di Malaysia, statistik pengguna Internet pada tahun 2011 adalah seramai 17,723,000 atau $61.7 \%$ daripada populasi rakyat Malaysia. ${ }^{1}$ Data ini jelas menunjukkan kepentingan Internet dalam kehidupan seharian penduduk di Malaysia sehinggakan Internet kini menjadi satu keperluan di kalangan rakyat Malaysia.

Perkembangan Internet ini secara tidak langsung telah membawa kepada lahirnya perbankan di atas talian ataupun juga

\footnotetext{
${ }^{1}$ Data yang diperoleh ini adalah sehingga 31 Disember 2011 Internet
} Usage Statistics, $2011 \mathrm{http}: / /$ www.internetworldstats.com/stats.htm dikenali sebagai perbankan Internet. Perbankan Internet ini membolehkan pelanggan untuk menjalankan transaksi kewangan di laman web bank-bank yang berkenaan dengan selamat. Ia juga sangat berguna dan menyediakan satu pendekatan yang mudah dan berguna untuk menguruskan kewangan seseorang kerana ia adalah boleh diakses 24 jam sehari dan tujuh hari seminggu. Terdapat pelbagai transaksi perbankan yang dapat dilakukan antaranya adalah seperti memeriksa baki akaun, membayar bilbil, memindahkan dana ke akaun lain dan sebagainya. ${ }^{2}$

Perbankan Internet merupakan satu perkhidmatan yang disediakan oleh pihak bank kepada pemegang akaun bank tersebut bagi memudahkan pelanggan mereka menguruskan hal kewangan dari rumah atau di tempat kerja atau di mana-mana sahaja yang mempunyai perkhidmatan mengakses Internet. Dengan kepesatan penggunaan Internet, urusniaga cara baru ini lama-kelamaan akan menguasai cara urusniaga zaman moden dan

2 Nauman Zahid et al. 2010. Consumer Acceptance of Online Banking European. Journal of Economics, Finance and Administrative Sciences 
menggantikan urusan perniagaan cara tradisional kerana ia menawarkan banyak kelebihan terutamanya ia menjimatkan masa serta tenaga dan memudahkan pelanggan. Oleh itu, ia telah menerima sambutan yang amat menggalakkan khususnya di negara-negara maju dengan penggunanya yang begitu meluas.

Namun, persoalan yang timbul adalah sejauh mana urusniaga menggunakan perantaraan Internet ini selaras prinsipprinsip Fiqh Mu'amalat yang telah dibincangkan oleh ahli-ahli fiqh sejak dahulu lagi. Dalam kajian ini juga akan membincangkan mengenai penjelasan terhadap persoalanpersoalan yang timbul dalam pelaksanaan perbankan Internet dari segi akad yang berlaku, pembentukan majlis akad dan kecacatan dalam akad yang berlaku dalam perbankan Internet.

\subsection{SOROTAN LITERATUR}

Sorotan kajian lepas amat penting untuk memberi gambaran awal mengenai sesuatu kajian. Dalam membuat sorotan ini, penulis telah meneliti dan mengkaji secara langsung kewujudan sumber yang berkaitan dengan akad dalam perbankan internet melalui rujukan jurnal, tesis, buku, kertas kerja dan sebagainya.

Nasrul Hisyam Nor Muhamad (2008) ${ }^{3}$ membincangkan mengenai aplikasi sains dan teknologi yang digunakan dalam transaksi muamalah Islam pada masa kini dan sejauhmana aplikasi sedemikian memenuhi justifikasi syarak dalam konteks Fiqh Muamalah. Penulis telah menggambarkan secara ringkas mengenai aplikasi sains dan teknologi dalam urusan transaksi muamalah Islam. Seterusnya perbincangan lebih fokus kepada rukun-rukun akad mengikut perspektif Undang-undang Kontrak Islam dan sejauhmana serta bagaimana ia diambil kira dalam transaksi muamalah dalam perkembangan sains dan teknologi hari ini.

Azlin Alisa Ahmad et al. (2008) ${ }^{4}$ telah membahaskan perniagaan Internet dari aspek maslahah dan mafsadah yang timbul daripadanya. Hasil dari kajian ini mendapati bahawa perniagaan Internet mampu memelihara kemaslahatan dan keharmonian masyarakat secara menyeluruh (maslahah 'ammah). Selain itu, pemakaian maslahah yang bersifat fleksibel mampu membawa ke arah kemajuan dan pemodenan serta tidak menghalang pembaharuan yang dibuat selaras dengan era globalisasi ini, khususnya urusniaga Internet yang tidak wujud hukumnya di dalam al-Quran dan al-Sunnah.

Nor Adila Mohd Noor dan Nor Azlina Mohd Noor $(2008)^{5}$ telah membincangkan teori akad dari perspektif muamalah Islam dan juga konvensional. Perbincangan penulis difokuskan kepada konsep kontrak yang diamalkan dalam transaksi jual beli edagang dan akad jual beli dalam transaksi muamalah Islam dengan membuat kajian perbandingan antara kedua-duanya. Penilaian secara kritis terhadap keseluruhan elemen dalam kontrak e-dagang juga telah dilakukan bagi memastikan sama ada ia bertepatan atau tidak dengan kontrak yang dikehendaki oleh syarak.

Rohaya Shaari et al. (2005) ${ }^{6}$ membincangkan pandangan pegawai bank terhadap perkhidmatan perbankan Internet. Penulis juga turut mengulas sedikit mengenai sejarah perbankan Internet di Malaysia. Dalam menjalankan kajian ini penulis telah mengedarkan borang soal selidik kepada pengurus bank di utara

\footnotetext{
${ }^{3}$ Nasrul Hisyam Nor Muhamad. 2008. Aplikasi Sains Dan Teknologi Dalam Transaksi Muamalah Islam: Rujukan Kepada Rukun-Rukun Akad Mengikut Perspektif Undang-Undang Kontrak Islam. Jurnal Teknologi. hh. 81-91

${ }^{4}$ Azlin Alisa Ahmad, Muhd Adib Samsuddin dan Mustafa 'Afifi Ab. Halim. 2008. Perniagaan Internet: Antara Maslahah Dan Mafsadah. Seminar Keusahawanan Islam II Peringkat Kebangsaan

${ }^{5}$ Nor Adila Mohd Noor dan Nor Azlina Mohd Noor. 2008. Kontrak EDagang: Perbandingan Aqad (Kontrak) Dalam Muamalah Islam
}

Malaysia. Hasil kajian mendapati walaupun perbankan Internet meningkatkan khidmat kepada pelanggan sebaliknya perbankan Internet dilihat mengurangkan sumber manusia dan hubungan bank-pelanggan. Oleh itu, kajian ini mencadangkan kepada pengurus bank untuk terus menawarkan khidmat peribadi kepada pelanggannya dan perbankan Internet digunakan untuk melengkapi dan meningkatkan operasi perbankan.

Muhammad Rizal Razman (2001) ${ }^{7}$ membincangkan mengenai transaksi perniagaan yang berlaku dalam e-dagang dari perspektif undang-undang Islam serta implikasinya terhadap pembangunan ummah. Kajian ini turut membahaskan mengenai konsep jual beli serta rukun dan syarat yang terlibat dalam proses jual beli. Hasil kajian mendapati bahawa jual beli yang dilakukan di alam maya adalah dibenarkan menurut perundangan Islam. Bagi memastikan jual beli ini sah, maka transaksi berkenaan mestilah memenuhi dan melaksanakan kesemua rukun yang digariskan dalam perundangan Islam.

Mat Noor Mat Zain dan Zamzuri Zakariz $(2001)^{8}$ membincangkan amalan e-dagang dengan menyentuh kedudukan akadnya dari perspektif muamalah Islam. Kajian ini juga menyentuh tentang pembentukan akad secara umum serta bagaimana akad berlaku dalam proses transaksi e-dagang. Penulis juga turut membincangkan mengenai pembatalan transaksi yang dilakukan dalam majlis akad iaitu khiyar majlis, khiyar al-ruju' dan juga khiyar al-qabul.

\subsection{METODOLOGI KAJIAN}

Dalam mencapai objektif kajian ini, penulis telah mengenal pasti beberapa kaedah atau metod kajian yang boleh digunakan di dalam mengumpul dan menganalisis data yang ditemui. Data yang diperolehi telah dikumpul dan dianalisis bagi menghasilkan sebuah kajian yang berautoriti dan mencapai objektif kajian yang dikehendaki.

Secara umumnya penyelidikan yang dijalankan menggunakan kaedah pengumpulan data iaitu melalui penyelidikan perpustakaan. Data yang diperolehi adalah daripada bahan-bahan yang terdiri daripada kitab bahasa Arab, buku perbankan dan kewangan Islam, jurnal dan pelbagai lagi bahanbahan yang terdapat di perpustakaan atau pusat sumber ilmu.

Untuk menganalisa data pula, tiga metode analisis data telah digunakan iaitu metode induktif, metode deduktif dan juga metode komparatif. Metode induktif ialah satu cara menganalisis data dengan mencari pembuktian daripada dalil yang bersifat khusus untuk mencapai dalil yang bersifat umum. Metode ini digunakan untuk membuat pendefinisian serta menjelaskan fungsi dan perkembangan perbankan Internet di Malaysia.

Manakala metode deduktif ialah satu cara menganalisis data serta melakukan penulisan berdasarkan fakta-fakta yang bersifat umum kepada fakta-fakta yang bersifat khusus. Metode ini digunakan untuk menganalisis akta-akta dan fatwa-fatwa semasa yang berkaitan dengan transaksi dalam perbankan Internet.

Metode komparatif pula ialah proses membuat perbandingan antara data-data yang dikumpul bagi memperolehi satu kesimpulan yang tepat dengan masalah kajian. Metode ini digunakan iaitu dengan membuat perbandingan di antara

\footnotetext{
${ }^{6}$ Rohaya Shaari et al. 2005. Internet Banking: from The Perspective of Malaysian Bankers. University Utara Malaysia

${ }^{7}$ Muhammad Rizal Razman. 2001. Transaksi Jual Beli Melalui Internet Dari Perspektif Islam: Implikasi Terhadap Pendidikan Ummah. Jurnal Pendidikan. 9(4) 41-50

${ }^{8}$ Mat Noor Mat Zain dan Zamzuri Zakariz. 2001. Pembentukan Akad Dalam E-Dagang. Seminar Kebangsaan Undang-undang Perbandingan. Universiti Kebangsaan Malaysia
} 
peruntukan yang ada di dalam akta dengan fatwa-fatwa atau kitab-kitab fiqh semasa.

\subsection{KONSEP AKAD DALAM ISLAM}

Akad ialah suatu kontrak yang terbina atas kehendak dua atau lebih pihak yang akan membawa sesuatu kesan hukum syarak. ${ }^{9}$ Menurut al-Jurjani, akad ialah ikatan perbuatan melalui proses tawar menawar (ijab) dan penerimaan (qabul).${ }^{10}$ Menurut istilah para fuqaha, jual beli ialah akad yang merujuk kepada pertukaran sesuatu harta dengan harta yang lain bagi tujuan pemilikan kekal. Maksudnya, dalam akad tersebut mestilah wujud pertukaran harta untuk tujuan pemilikan. Jual beli juga mesti membabitkan sesuatu yang syarak menilainya sebagai harta. Jual beli ini juga perlu membabitkan pemilikan dan penyerahan hak milik dan tidak boleh ditetapkan untuk tempoh tertentu sahaja. ${ }^{11}$

Fuqaha mazhab Maliki pula, mendefinisikan jual beli dari sudut syarak dengan suatu akad yang mengandungi pertukaran barangan antara kedua-dua pihak yang melakukan akad. Fuqaha mazhab Hambali pula mentakrifkan jual beli sebagai pertukaran barangan dengan barangan lain secara pertukaran hak milik. ${ }^{12}$ Fuqaha mazhab Syafie pula berpendapat bahawa jual beli menurut istilah syarak adalah pertukaran barangan dengan barangan lain melalui cara-cara yang tertentu. Walaupun definisidefinisi yang dikeluarkan oleh ahli-ahli Fiqh agak berbeza sedikit antara satu sama lain namun kesemua definisi-definisi tersebut sependapat dalam mengaitkan jual beli sebagai penukaran sesuatu dengan sesuatu.

Wahbah al-Zuhaily membahagikan definisi akad kepada dua kategori, umum dan khusus. Secara umumnya, akad ialah setiap perkara yang diniatkan oleh individu untuk dilakukannya sama ada ia hasil dari satu kehendak (sebelah pihak) seperti wakaf, pelupusan hutang, talak dan sumpah atau ia memerlukan dua kehendak (dua pihak) untuk dilaksanakan seperti jual beli, sewaan, perwakilan dan gadaian. Secara khususnya pula ia adalah ikatan antara ijab dan qabul yang mengikut syarak dan menghasilkan kesannya pada tempatnya. Ia adalah takrif yang biasa diguna pakai oleh ulamak Islam dalam mendefinisikan akad. $^{13}$

Setiap kontrak sudah tentu mempunyai rukun-rukun tersendiri supaya kontrak ini wujud. Rukun-rukun ini pula sudah tentu mempunyai syarat-syarat tersendiri supaya ia diterima sebagai sah dan seterusnya memberikan implikasi tertentu iaitu beberapa hukum yang ditetapkan oleh Allah S.W.T. Terdapat tiga rukun yang penting dalam akad jual beli iaitu Pihak yang mengikat Kontrak, Sighah kontrak (Ijab dan Qabul), Barang jualan dan harganya (Ma'qud 'alaih) ${ }^{14}$

\footnotetext{
${ }^{9}$ Zaharuddin Abd. Rahman. 2009. Panduan perbankan Islam kontrak dan produk asas. Kuala Lumpur: Telaga Biru. Hlmn. 2

${ }^{10}$ Ibid. Hlmn. 2

11 Zulkifli Mohammad Al-Bakri. 2011. Kewangan Islam dalam Fiqh Syafi'i. Kuala Lumpur: IBFIM. Hlmn. 16

12 Abi Muhammad Abdullah Ibn Ahmad. 1972. Al-Mughni. Juzuk 4. Beirut: Dar al-Kitab al-Arabi. Hlmn. 45

13 Al-Zuhayli, Wahbah. 1973. al-Fiqh al-Islami Wa Adillatuhu. Beirut: Dar al-Fikr. Hlmn. 363

14 Keterangan lebih lanjut mengenai setiap rukun-rukun tersebut boleh rujuk dalam Zulkifli Mohammad Al-Bakri. 2011. op.cit. Hlmn. 20 Lihat juga Faizah Haji Ismail. 1995. Asas-asas muamalat dalam Islam. Kuala Lumpur: Dewan Bahasa dan Pustaka. Hlmn. 71-110

15 Hazlina Abdul Kadir, Nasim Rahmani dan Reza Masinaei. 2011. Impacts of service quality on customer satisfaction: Study of Online banking and ATM services in Malaysia. International Journal of Trade, Economics and Finance. 2(1): 1-9
}

\subsection{PERBANKAN INTERNET DI MALAYSIA}

Aplikasi perbankan Internet terhadap produk perbankan Islam merupakan wadah untuk memperkembangkan lagi produk ini ke tahap yang lebih baik, para pelanggan menjadi lebih mudah untuk berurusniaga dengan pihak bank. Hal ini bermaksud, kedua-dua pihak mendapat faedah masing-masing. Usaha ini perlu diberi perhatian sewajarnya agar matlamat memartabatkan muamalah Islam dapat direalisasikan dan mampu bergerak seiring dengan produk konventional.

Perbankan Internet bermaksud penawaran produk dan perkhidmatan perbankan menerusi Internet oleh institusi-institusi perbankan dengan menggunakan pelbagai kemudahan akses termasuklah komputer dan peralatan canggih yang lain. Perbankan Internet juga boleh didefinisikan sebagai perkhidmatan yang tidak memerlukan pada sebarang perisian atau akses khas kepada sebuah rangkaian persendirian tetapi ianya dilakukan melalui rangkaian Internet. Perbankan Internet membolehkan pengguna menguruskan hal kewangan di manamana sahaja di serata dunia semasa atau diluar waktu perbankan.

Perkembangan teknologi yang semakin pesat menyebabkan institusi-institusi perbankan di Malaysia juga turut melangkah kehadapan dalam menyediakan perkhidmatan mengikut teknologi terkini. Maka dengan itu wujudnya saluran alternatif perkhidmatan bank melalui perbankan elektronik seperti Automatic Teller Machine (ATM), phone banking, PC banking dan perbankan Internet sebagai alat pemudah cara. ${ }^{15}$

Bentuk saluran elektronik terawal yang jelas kelihatan dalam industri perbankan Malaysia ialah kemunculan ATM pada tahun 1981.16 Satu lagi jenis saluran elektronik telah diperkenalkan sekitar tahun 1990-an ialah phone-banking. ${ }^{17}$ Kaedah penyampaiannya adalah berbeza yang mana pelanggan perlu membuat panggilan dan menembusi sistem Automated Voice Response (AVR) untuk mendapatkan bantuan perkhidmatan bank. Generasi ketiga dalam revolusi perbankan elektronik pula ialah $P C$-banking atau juga dikenali sebagai desktopbanking. Kaedah ini memerlukan kos yang agak tinggi untuk memasang kemudahan intranet dan membeli perisian yang berkaitan. Oleh itu, ianya lebih popular di kalangan pelanggan korporat berbanding pelanggan perseorangan. ${ }^{18}$ Kemudian diikuti pula oleh perbankan internet.

Pada 1 Jun 2000 Bank Negara Malaysia telah memberikan kebenaran untuk bank komersial tempatan untuk menyediakan perkhidmatan perbankan Internet. Berikutan daripada itu, Malayan Bank (Maybank) sebagai korporat perbankan yang terbesar di Malaysia telah memulakan perkhidmatan perbankan Internet kepada pelanggannya pada 15 Jun 2000 dengan memperkenalkan maybank2u.com. ${ }^{19}{ }^{20}$ Bagaimanapun, tahap berjayanya saluran baru ini untuk produk dan perkhidmatan perbankan bergantung kepada peningkatan kegunaan teknologi baru yang diaplikasikan oleh pengguna Malaysia secara runcit ataupun korporat.

${ }^{16}$ Suganthi, R., Balachandher, K.G., dan Balachandran, V. 2001. Internet banking patronage: An empirical investigation of Malaysia. Journal of Internet Banking and Commerce. 6(1)

${ }^{17}$ Guru, B.K., Vaithilingam, S., Norhazlin Ismail dan Prasad. R. 2000. Electronic banking in Malaysia: A note on evolution of services and consumer reactions. Journal of Internet Banking and Commerce. $5(1)$.

${ }^{18}$ Suganthi, R., Balachandher, K.G., dan Balachandran, V. 2001. op.cit.

19 Bank Negara Malaysia. Ucapan perasmian Gabenor Bank Negera pada 9 Jun 2000 diambil pada 13 November 2012 daripada http://www.bnm.gov.my/index.php?ch=en_speech\&pg=en_speech all\&ac=36\&lang=en

20 Dewan Masyarakat (April, 2011) diambil pada 2 November 2012 daripada http://dwnmasyarakat.dbp.my/?p=1497 ; Lihat Utusan Online setelah setahun kemunculannya di Malaysia http://www.utusan.com.my/utusan/info.asp?y=2001\&dt=0726\&pu $\mathrm{b}=$ Utusan_Malaysia\&sec=Megabait\&pg=me_01.htm 
Hong Leong Bank pula telah menyediakan perkhidmatan perbankan Internet pada Disember 2000. Kemudiannya Southern Bank $^{21}$ juga memperkenalkan perbankan internet. Sehingga awal abad ke-21 ini, didapati perbankan Internet telah dijadikan sebagai satu perkhidmatan asas yang harus dibekalkan oleh perbankan korporat Malaysia. Hanya institusi-institusi perbankan yang dilesenkan di bawah Akta Bank dan Institusi-Institusi Kewangan 1989 (ABIK) dan Akta Perbankan Islam 1983 (API) sahaja yang dibenarkan untuk menawarkan perkhidmatan perbankan Internet di Malaysia. ${ }^{22}$ Boleh dikatakan kebanyakan bank yang terdapat di Malaysia telah menawarkan perkhidmatan perbankan secara Internet.

\subsection{AKAD DALAM PERBANKAN INTERNET}

\subsection{Pembentukan Akad}

Menurut Jumhur fuqaha', akad terbentuk daripada lafaz tawaran, penerimaan, pemberi tawaran, penerimanya dan subjek tawaran itu sendiri. ${ }^{23}$ Walau bagaimanapun, fuqaha Mazhab Hanafi pula mengatakan bahawa rukun akad itu sebenarnya hanyalah tawaran dan penerimaan sahaja. Manakala yang selain daripada itu dinamakan sebagai keperluan semata-mata. Ini disebabkan tawaran dan penerimaan memerlukan orang yang membuat dan menerima tawaran itu. Maka sudah semestinya pula ada benda atau perkara yang ditawarkan. ${ }^{24}$

Dalam transaksi perbankan Internet, pihak bank merupakan pihak yang menawarkan subjek akad yang merupakan perkhidmatan yang disediakan oleh pihak bank secara maya. Pengguna perkhidmatan perbankan pula merupakan pihak yang menerima subjek akad iaitu perkhidmatan yang ditawarkan oleh pihak bank. Pengguna perkhidmatan ini boleh membuka laman sesawang bank- bank tertentu bagi melihat tawaran perkhidmatan yang disediakan oleh pihak bank.

Melakukan akad dengan menggunakan alat komunikasi terkini seperti telefon boleh berlaku secara menggunakan lafaz yang terus ataupun dengan menggunakan tulisan seperti pos, faks atau telegraf. Pembentukan akad ijab dan qabul di dalam perbankan Internet adalah secara dokumen bertulis menerusi jaringan Internet dengan menggunakan peralatan komputer. Dengan ini, komunikasi asas dalam melakukan akad melalui perbankan Internet adalah berdasarkan penulisan atau dokumen. Melakukan akad secara maya adalah berasaskan kepada konsep berakad di antara pihak-pihak yang berjauhan (al-gha'iban) iaitu tidak bersama-sama pada satu masa dan tempat. ${ }^{25}$

Ijab yang dibuat oleh pihak bank dilakukan secara terus melalui laman web aktif terbuka dengan mengatur program tertentu yang boleh dicapai oleh pemegang akaun bank tertentu yang berminat untuk melakukan akad seperti yang diprogramkan. ${ }^{26}$ Pihak bank perlu memberi maklumat secara terperinci ke atas perkhidmatan yang ditawarkan sehingga boleh menghilangkan kekaburan atau kesamaran kepada pengguna perkhidmatan perbankan Internet terhadap perkhidmatan yang ditawarkan. Dengan itu ijab boleh diambil kira dan ia akan kekal sehinggalah tampil mana-mana pihak yang menerimanya. Ijab yang ditujukan pada umum tidak akan berhenti dan berakhir, sebaliknya ia akan berterusan sehinggalah ijab ini bersambungan

\footnotetext{
${ }^{21}$ Kini dijadikan sebagai CIMB Bank dengan gabungan Bank Bumiputra Commerce Berhad (BCB)

${ }^{22}$ Bank Negara Malaysia, Info Perbankan Perbankan Internet diambil pada 2 Oktober 2012

${ }^{23}$ Faizah Haji Ismail. 1995. op.cit. Hlmn. 70

${ }^{24}$ Nasrun Haroen. 2000. Fiqh Muamalah. Jakarta: Gaya Media Pratama. Hlmn. 99
}

dengan sesuatu penerimaan ataupun terjadi sesuatu rintangan dan halangan yang membatalkannya. ${ }^{27}$

Penerimaan daripada pihak yang ingin mengadakan akad pula pada kebiasaannya berlaku setelah diisi segala maklumat yang dikehendaki dan bersetuju dengan cara tertentu mengikut program yang ditetapkan oleh bank. Penerimaan tawaran oleh pengguna perbankan Internet tidak boleh berlaku secara serta merta dengan melihat tawaran perkhidmatan yang disediakan kerana selain terpaksa mengisi segala maklumat yang diingini, pelanggan terlebih dahulu perlu memilih perkhidmatan yang ingin digunakan.

Ahli-ahli Fiqh telah bersepakat bahawa salah satu syarat bagi ijab dan qabul ialah kedua-duanya mesti bersambung tanpa diselangi oleh sesuatu yang tidak berkaitan dengannya. Akan tetapi, dalam menentukan apakah yang dimaksudkan dengan bersambungan ijab dengan qabul ahli-ahli Fiqh berselisih pendapat. Mazhab Shafi'i berpendapat qabul mestilah lahir segera atau serta-merta selepas ijab tanpa ada pemisah walaupun sedikit yang tidak berkaitan dengan akad. Walau bagaimanapun, bagi mengelakkan pihak yang berakad menyesal kerana perlu membuat keputusan segera sebaik sahaja menerima ijab, Mazhab Shafi'i mengenengahkan konsep khiyar majlis yang memberi kebebasan kepada orang yang berakad untuk melakukan pilihan sama ada untuk meneruskan akad tersebut atau sebaliknya asalkan mereka berdua masih berada dalam majlis akad. ${ }^{28}$

Manakala Mazhab Hanafi dan Hanbali berpendapat bahawa maksud bersambungan itu ialah bersambungnya ijab dan qabul dalam satu majlis. Ini bermakna apabila lahirnya ijab daripada salah seorang maka qabul tidak semestinya lahir dengan segera atau serta-merta daripada salah seorang lagi. Namun, qabul boleh lahir kemudian untuk beberapa ketika selama mana majlis akad masih berjalan di mana kedua-duanya masih berada dalam majlis akad tersebut.

Dalam perbankan internet, khiyar majlis tidak akan berlaku sama sekali. Ini berikutan kerana pihak bank dan pelanggan tidak bertemu atau berinteraksi secara langsung yang mana ianya sama seperti akad bertulis dengan menggunakan surat menyurat di antara satu sama lain. Oleh itu, aplikasi perbankan Internet berpegang pada pandangan Mazhab Hanafi dan Hanbali kerana ia memberikan ruang masa kepada orang yang berakad sama ada kepada pihak bank atau pelanggan itu sendiri untuk berfikir dan membuat pertimbangan sama ada mahu meneruskan akad tersebut atau sebaliknya.

\subsection{Majlis Akad}

Majlis akad terbentuk berdasarkan syarat sighah yang mengkehendaki ijab dan qabul berkesinambungan diantara satu sama lain dalam majlis. Majlis akad ialah suatu keadaan di mana kedua-dua pihak berakad bersemuka mencari persepakatan mengenai akad ataupun majlis pertemuan melakukan akad. ${ }^{29}$ Majlis akad bermatlamat untuk menghadkan tempoh masa yang mungkin memisahkan penerimaan dengan tawaran tanpa memudaratkan pembuat dan penerima tawaran. Ia juga memberi ruang kepada pihak-pihak berakad untuk mengetahui pendirian pihak satu lagi kerana akad terbentuk dengan kehendak dan ianya satu perkara yang tersembunyi.

Dalam majlis akad, penawaran dan penerimaan boleh dilakukan dalam dua keadaan iaitu sama ada kedua-dua pihak

\footnotetext{
${ }_{25}^{25}$ Mat Noor Mat Zain dan Zamzuri Zakariz. 2001. op.cit. Hlmn. 9

${ }^{26}$ Ibid. Hlmn. 9

27 Ibid. Hlmn. 9

28 Shams al-Din Muhammad Ibn Muahammad al-Khatib al-Sharbini. t.t. Mughni al-Mukhtãj. Dar al-Fikr. Jil. 2. Hlm. 43

${ }^{29}$ Mat Noor Mat Zain dan Zamzuri Zakariz. 2001. op.cit. Hlmn.11
} 
hadir bersama di dalam satu majlis ataupun dalam satu majlis tetapi satu pihak tidak hadir namun beliau mengetahui penawaran dibuat. Terdapat beberapa keadaan jika satu pihak tidak hadir di dalam majlis akad. Pertama, berkontrak dengan orang yang tidak ada dalam majlis (ghaib). Jika salah satu pihak membuat tawaran bagi menjual atau membeli sedangkan satu pihak lagi tidak ada dalam majlis tersebut, kemudian tawaran tersebut sampai kepadanya lalu pihak tersebut menerimanya. Maka kontrak tersebut adalah sah. Tetapi jika tawaran itu tidak dipersetujui olehnya maka kontrak itu terbatal.

Kedua, kontrak berlaku dengan orang perantaraan. Salah seorang daripada kedua-dua pihak yang berkontrak mengutuskan seorang utusan atau wakilnya kepada seorang yang lain untuk menjalankan kontrak tersebut. Kontrak tersebut adalah sah. Ini kerana orang yang diutuskan itu merupakan penyampai kata orang yang mengutuskannya. Orang yang mengutus seolah-olah hadir sendiri dan mengungkapkan tawaran lalu diterima oleh pembeli. Oleh itu kontrak tersebut adalah sah.

Ketiga pula adalah kontrak melalui surat. Salah satu pihak yang berhajat untuk berkontrak telah menulis surat kepada satu pihak lain yang ingin berkontrak. Surat boleh ditulis dalam apaapa bahasa sekalipun dengan syarat kedua-dua belah pihak yang berakad memahami maksud surat itu. Berdasarkan pendapat ini, tidak ada perbezaan sama ada pernyataan secara bertulis dilakukan oleh kedua-dua pihak atau satu pihak sahaja sedangkan satu pihak lagi menyatakannya secara lisan. ${ }^{30}$ Penulis boleh menarik balik surat penawaran dengan syarat dihadapannya ada saksi. Namun, menurut mazhab Maliki tidak boleh menarik balik sebelum penerima surat diberi peluang untuk membuat pilihan dalam tempoh yang ditentukan oleh uruf.

Akad yang terbentuk dalam transaksi perbankan Internet ini adalah berdasarkan tulisan atau dokumen digital, maka ianya boleh dikira sebagai akad yang dilakukan oleh pihak-pihak yang berjauhan sama seperti berakad melalui surat. Oleh yang demikian, majlis akad bagi transaksi ini bermula sebaik sahaja dokumen atau tulisan daripada pihak bank sampai atau diterima oleh pihak pengguna perbankan Internet. Apabila tawaran yang berbentuk tulisan diterima oleh pengguna dan dinyatakan persetujuannya, maka terbentuklah akad di antara pihak bank dan pengguna perbankan Internet. Majlis akad ini berakhir sebaik sahaja pelanggan menamatkan penggunaannya. ${ }^{31}$ Setelah majlis itu berakhir mana-mana pihak tidak boleh untuk memfasakhkan akad tersebut melainkan dengan persetujuan pihak satu lagi. ${ }^{32}$

\subsection{Kecacatan dalam Akad}

Dalam perbankan Internet, keredaan yang berlaku adalah sama dengan keredaan yang berlaku di dalam transaksi secara tradisional. Di mana sesuatu akad itu tidak boleh disertakan dengan perkara yang membawa kecacatan akad yang memboleh membatalkan akad seperti ketidakpastian (gharar). Oleh yang demikian, kedua-dua pihak yang berakad perlu memastikan perkara yang mencatatkan akad tidak terdapat di dalam transaksi bagi memastikan kedua-dua pihak berpuas hati dengan transaksi yang dilakukan.

Menurut Al-Kasani gharar ialah suatu bahaya bagi perjanjian dalam perniagaan dengan adanya keraguan tentang hasilnya samada wujud ataupun tidak. ${ }^{33}$ Manakala Imam Nawawi

\footnotetext{
${ }^{30}$ Faizah Haji Ismail. 1995. op.cit. Hlmn. 76; Lihat Ibn 'Abidin. 1327H. Hasyiah Rad al-Mukhtar. Kaherah: Matba'ah al-Maimaniyah. Jil. 4. Hlmn. 10

${ }^{31}$ Nasrul Hisyam Nor Muhamad. 2008. op.cit. Hlmn. 85

${ }^{32}$ Mat Noor Mat Zain dan Zamzuri Zakariz. 2001. op.cit. Hlmn. 11; Lihat Ibn 'Abidin. 1327H. op.cit. Jil. 4. Hlmn. 10

33 Al-Kasani. 1910. Badal al-sanai' fi tartib al-syara'i. Kaherah: Matba'ah Jamaliah. Jil. 5. Hlmn. 263
}

menyatakan gharar adalah sesuatu yang tersembunyi keadaannya bahkan tersembunyi pula akibat kemudiannya selepas akad. ${ }^{34} \mathrm{Ibn}$ Taimiyah pula mendefinisikan gharar sebagai suatu kontrak yang tidak dapat dipastikan hasilnya di akhir akad nanti. ${ }^{35}$ Apa yang jelas semua definisi-definisi tersebut membawa kepada maksud yang sama iaitu gharar merupakan satu keadaan yang tidak pasti akan keberhasilan akad yang dilakukan dalam transaksi iaitu akan menyebabkan berlakunya keraguan tentang hasilnya atau memberi kesan yang negatif selepas berlakunya transaksi.

Konsep gharar atau ketidakpastian ini boleh berlaku di dalam perbankan Internet akan tetapi nisbah berlakunya masalah ini adalah sangat kecil. Ini kerana ianya dapat diatasi dengan protokol dan sistem tertentu yang menyebabkan sukarnya berlaku sesuatu penipuan atau ketidakpastian. Sebelum pengguna perbankan Internet melakukan transaksi kebiasaanya pengguna akan dinasihati oleh pihak bank supaya memahami terma dan syarat-syarat perkhidmatan terlebih dahulu sebelum mendaftar untuk perkhidmatan perbankan Internet. Ianya bertujuan untuk mengenal pasti atau menyalurkan sebarang maklumat baru kepada pihak bank. ${ }^{36}$

Perkhidmatan perbankan Internet juga merangkumi maklumat tentang tanggungjawab institusi perbankan dan pelanggan. Selain itu ianya juga turut merangkumi tentang pihak yang harus bertanggungjawab sekiranya berlaku sebarang transaksi palsu atau penipuan. Maklumat berkaitan dengan cara membuat aduan dan bagaimana aduan itu disiasat dan diselesaikan juga turut disediakan supaya sebarang masalah yang timbul seperti penipuan dan ketidakpastian yang berlaku di dalam transaksi dapat diselesaikan oleh pihak bank yang bertanggungjawab.

\subsection{PANDANGAN ISLAM TERHADAP PERBANKAN INTERNET}

Pada zaman dahulu perbankan internet ini tidak wujud sama sekali. Kemajuan dunia pada masa kini telah membawa kepada pelbagai persoalan dan menuntut fiqh Islam mengemaskini furu' hukum yang tidak wujud pada zaman pembinaan hukum. ${ }^{37}$ Unsur-unsur perkembangan teknologi yang terkini ini dalam pembentukan akad adalah dibenarkan selagi mana ianya mematuhi peraturan yang ditetapkan oleh syarak. Dalam meniti ke arah kemajuan teknologi, hukum syarak tetap perlu ditekankan dalam setiap aspek agar tidak terpesong jauh dari jalan yang benar.

Menurut fatwa yang dikeluarkan oleh persidangan Majma al-Fiqh al-Islami Kali ke-6 di Jeddah pada 17-23 Syaban $1420 \mathrm{H}$ bersamaan 14-20 Mac 1990M. Antara keputusan yang telah dibuat pada persidangan tersebut ialah apabila berlaku akad antara dua orang yang tidak berada di satu tempat, masingmasing tidak melihat dan mendengar antara satu sama lain, perantaraan antara mereka ialah dengan tulisan, surat atau menghantar utusan, termasuk juga telegram, faks atau komputer maka dalam keadaan ini akad yang dilakukan antara kedua-dua menjadi sempurna apabila sesuatu tawaran itu sampai kepada penerima tawaran dan dia menerimanya. ${ }^{38}$

Oleh itu, ini jelas menunjukkan bahawa transaksi yang dilakukan dengan menggunakan perkhidmatan perbankan

\footnotetext{
34 Al-Nawawi. 1966-89. Al-majmuk' sharh al-muhadhab. Kaherah: Matba'at al-'Asimah. Jil.9. Hlmn. 310

${ }^{35}$ Ibn Taimiyyah. t.t. Majmu'ah fatawa. Beirut: Dar al-Fikr. Jil. 3. Hlmn. 275

${ }^{36}$ Bank Negara Malaysia, op.cit.

${ }^{37}$ Nasrul Hisyam Nor Muhamad. 2008. Hlmn. 91

${ }^{38}$ Zamzuri Zakaria \& Mat Noor Mat Zain. 2008. Jual beli dalam e-dagang menurut perspektif muamalat Islam. Isu Figh dan Persoalan Semasa. Universiti Kebangsaan Malaysia. Hlmn. 534
} 
Internet dibolehkan bersandarkan akad yang dilakukan antara dua orang yang ghaib dan perantaraan mereka hanya melalui dokumen yang terdapat di laman sesawang setiap bank-bank yang terlibat. Berdasarkan hukum syarak, perbankan internet secara konsepnya adalah harus menurut pandangan Islam dan ini membuktikan bahawa Islam adalah satu agama yang lengkap yang mencakupi setiap aspek dalam kehidupan manusia.

\subsection{KESIMPULAN}

Kesimpulan yang dapat dibuat berdasarkan perbincangan ini ialah akad yang terdapat di dalam perkhidmatan perbankan Internet dilakukan secara bertulis yang melalui dokumen bertulis digital yang disediakan oleh pihak bank dengan menggunakan peralatan komputer. Akad ini dapat disandarkan dengan pembentukan akad secara tulisan atau al-kitabah yang dibenarkan dalam proses berlakunya akad malah ianya juga telah diterima pakai oleh para sarjana Islam. Akad secara maya ini juga boleh disandarkan kepada akad yang dilakukan oleh pihak yang berjauhan atau gha'ib ketika melakukan akad iaitu kedua-dua pihak tidak bersama pada satu tempat dan masa semasa majlis akad berlangsung.

Sekalipun zaman sentiasa beredar dan manusia semakin maju dari segi pemikiran dan daya kretiviti mereka lalu membawa kepada penciptaan alat-alat moden yang memudahkan perhubungan sesama mereka, Islam tidak menghalang kemajuan tersebut malah memberi galakan supaya mengejar kebahagiaan dunia bersama-sama dengan kebahagiaan akhirat. Hakikat ini membuktikan keanjalan Islam dalam meraikan suasana sebenar.

\section{Rujukan}

Abi Muhammad Abdullah Ibn Ahmad. 1972. Al-Mughni. Juzuk 4. Beirut: Dar al-Kitab al-Arabi.

Al-Kasani. 1910. Badal al-sanai' fi tartib al-syara'i. Kaherah: Matba'ah Jamaliah.

Al-Nawawi. 1966-89. Al-majmuk' sharh al-muhadhab. Kaherah: Matba'at al-'Asimah.

Al-Zuhayli, Wahbah. 1973. al-Fiqh al-Islami Wa Adillatuhu. Beirut: Dar alFikr.
Azlin Alisa Ahmad, Muhd Adib Samsuddin dan Mustafa 'Afifi Ab. Halim. 2008. Perniagaan Internet: Antara Maslahah Dan Mafsadah. Seminar Keusahawanan Islam II Peringkat Kebangsaan.

Bank Negara Malaysia. Info Perbankan Perbankan Internet.

Faizah Haji Ismail. 1995. Asas-asas Muamalat dalam Islam. Kuala Lumpur: Dewan Bahasa dan Pustaka.

Guru, B.K., Vaithilingam, S., Norhazlin Ismail dan Prasad. R. 2000 Electronic banking in Malaysia: A note on evolution of services and consumer reactions. Journal of Internet Banking and Commerce. 5.

Hazlina Abdul Kadir, Nasim Rahmani dan Reza Masinaei. 2011. Impacts of Service Quality on Customer Satisfaction: Study of Online Banking and ATM Services in Malaysia. International Journal of Trade, Economics and Finance. 2(1): 1-9.

Ibn 'Abidin. 1327H. Hasyiah Rad al-Mukhtar. Kaherah: Matba'ah alMaimaniyah

Ibn Taimiyyah. t.t. Majmu'ah fatawa. Beirut: Dar al-Fikr.

Mat Noor Mat Zain dan Zamzuri Zakariz. 2001. Pembentukan Akad Dalam E-Dagang. Seminar Kebangsaan Undang-undang Perbandingan. Universiti Kebangsaan Malaysia.

Muhammad Rizal Razman. 2001. Transaksi Jual Beli Melalui Internet Dari Perspektif Islam: Implikasi Terhadap Pendidikan Ummah. Jurnal Pendidikan. 9(4): 41-50.

Nasrul Hisyam Nor Muhamad. 2008. Aplikasi Sains Dan Teknologi Dalam Transaksi Muamalah Islam: Rujukan Kepada Rukun-Rukun Akad Mengikut Perspektif Undang-Undang Kontrak Islam. Jurnal Teknologi. 49(E): 81-91.

Nasrun Haroen. 2000. Fiqh Muamalah. Jakarta: Gaya Media Pratama.

Nauman Zahid et al. 2010. Consumer Acceptance of Online Banking. European Journal of Economics, Finance and Administrative Sciences.

Nor Adila bt Mohd Noor dan Nor Azlina Mohd Noor. 2008. Kontrak EDagang: Perbandingan Aqad (Kontrak) dalam Muamalah Islam.

Rohaya Shaari et al. 2005. Internet Banking: from The Perspective of Malaysian Bankers. University Utara Malaysia.

Shams al-Din Muhammad Ibn Muahammad al-Khatib al-Sharbini. t.t. Mughni al-Mukhtãj. Dar al-Fikr.

Suganthi, R., Balachandher, K.G., dan Balachandran, V. 2001. Internet banking patronage: An empirical investigation of Malaysia. Journal of Internet Banking and Commerce. 6.

Utusan Malaysia Online. Perbankan Internet - Masa depan dan penerimaannya di Malaysia. http://www.utusan.com.my/utusan/info.asp?y=2001\&dt=0726\&pub=U tusan_Malaysia\&sec=Megabait\&pg=me_01.htm.

Zaharuddin Abd. Rahman. 2009. Panduan Perbankan Islam Kontrak dan Produk Asas. Kuala Lumpur: Telaga Biru.

Zamzuri Zakaria \& Mat Noor Mat Zain. 2008. Jual Beli dalam e-dagang Menurut Perspektif Muamalat Islam. Isu Fiqh dan Persoalan Semasa. Universiti Kebangsaan Malaysia.

Zulkifli Mohammad Al-Bakri. 2011. Kewangan Islam dalam Fiqh Syafi'i. Kuala Lumpur: IBFIM. 